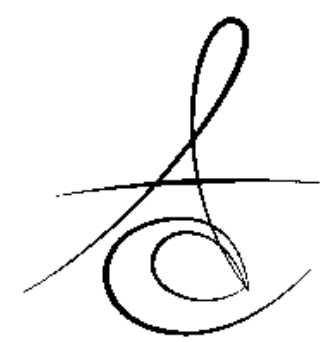

Makale Kodu/Article code: 2931

Makale Gönderilme tarihi; 13.07 .2016

Kabul Tarihi; 30.09 .2016

\title{
EVALUATION OF TREATMENT RESULTS AND STABILITY IN PATIENTS WITH ANTERIOR OPEN BITE TREATED BY PREMOLAR EXTRACTIONS OR MINI- IMPLANT ANCHORED INTRUSION
}

\section{PREMOLAR ÇEKİMLERİ VEYA MİNİ VİDA DESTEKLİ İNTRÜZYON İLE TEDAVİ EDİLMİ̧̧ ÖN AÇIK KAPANIŞLI HASTALARDA TEDAVİ SONUÇLARININ VE STABİLİTENİN DEĞERLENDİRİLMESİ}

\author{
Dr. Işıl ARAS*
}

\section{ABSTRACT}

Aim: The aim of this study was to compare the treatment results and stability of open bite treatment achieved via intrusion of posterior teeth and extraction of $1^{\text {st }}$ premolars

Material and Methods: This study was conducted on pretreatment (T1), posttreatment (T2) and follow-up (T3) cephalograms of 28 patients who received open bite treatment. 14 patients (mean age $14.61 \pm 0.87$ ) were treated with the extraction of the $1^{\text {st }}$ premolar (extraction group: EG) while 14 patients (mean age $15.06 \pm 1.05$ ) had bite closure via intrusion of the posterior teeth using mini-implants (miniimplant group: MG). The mean follow-up periods in EG and MG were $3.32 \pm 1.25$ (range, 2.10-6.20) and $2.74 \pm 0.77$ years (range, 2.05-4.34), respectively.

Results: At T2, SNB increased and SNGoGn decreased significantly in MG, with significant intergroup difference $(p<0.05)$. Maxillary and mandibular incisors extruded significantly in both groups, with greater amounts in EG $(p<0.05)$. Maxillary and mandibular incisors' inclinations decreased significantly in EG, with a significant intergroup difference $(p<0.05)$. Maxillary posterior teeth intruded significantly in $M G$, with a significant intergroup difference $(p<0.05)$. At T3, significant intrusion of upper incisors and extrusion of posterior teeth were observed in EG and MG, respectively, and these measurements showed significant intergroup differences $(p<0.05)$. Decreases in overbite were significant in both groups, with no intergroup difference. The clinically significant relaps rates were $7.14 \%$ (1 patient) and $14.28 \%$ (2 patients) in MG and EG, respectively.

Conclusion: Even though mini-implant supported intrusion and extraction therapy achieved bite closure via different treatment effects, both groups showed similar relaps tendencies at the follow-up.

Keywords: open bite, tooth extraction, tooth intrusion

\section{öz}

Amaç: Bu çalışmanın amacı 1. Premolar çekimi ve maksiller posterior dişlerin intrüzyonu ile gerçekleştirilen açık kapanış tedavilerinin sonuç ve stabilitesinin karşılaştırımasıdır.

Gereç ve Yöntem: Bu çalışma açık kapanış tedavisi gören 28 hastanın tedavi öncesi (T1), tedavi sonrası (T2) ve takip (T3) sefalometrik röntgenleri üzerinde yürütüldü. 14 hastada (ortalama yaş $14.61 \pm 0.87$ ) 1. Premolar çekimli konvensiyonel

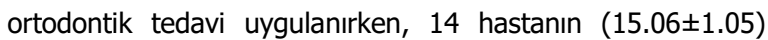
tedavisi posterior dişlerin intrüzyonu ile yapıldı. Çekim ve mini-implant gruplarında ortalama takip zamanları sırası ile $3.32 \pm 1.25$ ve $2.74 \pm 0.77$ yıldı.

Bulgular: Tedavi sonunda mini-implant grubunda, SNB açısındaki artış ve SNGoGn açısındaki azalma önemli bulundu $(p<0.05)$. Bu ölçümler bakımından gruplar arasındaki fark da önem bulundu $(p<0.05)$. Maksiller ve mandibular kesici dişler çekim grubunda daha fazla olmak üzere her iki grupta da önemli ekstrüzyon gösterdi $(p<0.05)$. Tedavi sonunda gruplar arasında önemli bir fark ile, mini-implant grubunda maksiller posterior dişlerin intrüzyonu önemli bulundu $(p<0.05)$. T3 döneminde, çekim grubunda üst keserlerde önemli intrüzyon gözlemlenirken, mini-implant grubunda posterior dişlerin ekstüzyonu önemli bulundu ve bu değerler bakımından gruplar arasındaki farklar da önem çıktı $(p<0.05)$. T3'de saptanan overbite miktarındaki azalmalar her iki grupta da önemli bulunurken $(p<0.05)$, gruplar arsındaki fark önemsizdi ( $p>0.05)$. Klinik olarak önemli relaps oranları miniimplant ve çekim gruplarında sırası ile \%7.14 (1 kişi) ve \%14.28 (2 kişi) olarak belirlendi.

Sonuç: Mini-implantlarla intrüzyon ve çekimli tedaviler farklı yollarla açık kapanışın tedavinde başarılı olsa da, her iki grubun takip sürecinde relaps eğilimleri benzer bulunmuştur. Anahtar Kelimeler: açık kapanış, diş çekimi, diş gömülmesi

\footnotetext{
${ }^{*}$ Department of Orthodontics, Faculty of Dentistry, Ege University, Izmir, Turkey
} 


\section{INTRODUCTION}

One way or another, clinicians achieve a successful treatment of open bite. The real challenge lies in preserving the achieved bite closure. Even though, there is a consensus that no pretreatment variable would be a reliable predictor for stability ${ }^{1-4}$, there exists some valuable data on treatment-related parameters. In their meta-analysis, Greenlee et al. ${ }^{5}$ calculated a stability rate of $75 \%$ and $82 \%$ for nonsurgical and surgical corrections of open bite, respectively. In non-surgical corrections, the reported relaps rates via variety of methods range between $8 \%$ $46 \% 6,7$. More specifically several authors have suggested that extraction treatment offered more stable results compared to non-extraction treatment protocols ${ }^{8,9}$. Additionally, extrusion of anterior teeth with elastics has not been recommended due to it is volatile nature in bite closure ${ }^{9,10}$ and for induction of root resorption of incisors ${ }^{3,11}$. Hence the ultimate goal in the treatment of skeletal open bite is achieving counterclockwise rotation of the mandible.

To achieve closing rotation of the mandible via relatively conservative options either extractions of the most anteriorly occluding teeth are carried out with the intention of protraction of the posterior teeth into the extraction space or posterior dentoalveolar intrusion is executed. de Freitas et al. ${ }^{12}$ investigated sole extraction treatment at the long term; however differential extraction patterns were not discriminated with several combinations of extracted teeth. Also some patients were reported to receive maxillary expansion and some individuals had extraoral reinforcement of anchorage as well as the myofunctional therapy. Thus the stability reported was a combination of all the forementioned treatment modalities.

On the other hand, mini-implant usage has been recommended to achieve posterior intrusion of the dentoalveolar segments as an alternative to orthognathic surgery resulting in autorotation of the mandible as increased molar heights has been reported as a common finding of skeletal open bite patients ${ }^{13}$. Though there is no consensus concerning the absolute limit for the necessity of orthognathic surgery, lesser the severity of the apical base discrepancy and accompanying dental compensations, the greater the likelihood of a successful treatment accomplished dentally. Of the 2 studies investigating long-term effects of molar intrusion via mini-implants, Baek et al.'s $\mathrm{s}^{4}$ study group consisted of 9 patients of whom 3 had also extractions and different methods of intrusion were used, while Scheffler et al. ${ }^{14}$ used either mini-plates or mini-implants with varying points of force application.

It is clear that studies investigating the long term stability of open bite correction that are treated in a standardized manner are needed. Thus the primary purpose of this study was to compare the posttreatment stability of open bite correction using either first premolar extraction therapy or mini-implant supported intrusion of posterior teeth. To be able to evaluate the stability of changes achieved by treatment, documentation of the treatment-induced changes was also to be determined as a secondary aim of this study.

\section{MATERIAL AND METHODS}

This retrospective research was conducted on lateral cephalometric radiographs of patients treated between the years of 2009-2014. The study protocol was approved by Ethics Committee of the School of Medicine, Ege University.

The pretreatment selection criteria for the groups were (1) an anterior open bite of at least 2 $\mathrm{mm}$ (2) minimum to moderate crowding dentitions (3) hyperdivergent growth pattern with SN-GoGn $\geq 37$ (4) presence of maxillary and mandibular permanent teeth up to the $2^{\text {nd }}$ molars. As for the posttreatment inclusion criteria, it was paid attention that (1) at least $1.5 \mathrm{~mm}$ of overbite was achieved at the end of the treatment (2) maxillary and mandibular anterior fixed retainers were bonded. 14 patients ( 8 girls 6 boys, mean age $14.61 \pm 0.87$ ) in the extraction group (EG) were treated with $1^{\text {st }}$ premolar extractions while 14 patients ( 9 girls 5 boys, mean pre-treatment age of $15.06 \pm 1.05$ ) in the mini-implant group (MG) were treated with the intrusion of premolars and molars. All patients had received orthodontic treatment with 0.018-inch preadjusted appliances. Minimum to moderate anchorage space closure using conventional methods were implemented in EG. In MG, after leveling and aligning $0.017 \times 0.025$-inch stainless steel (SS) wires were inserted as the main arch that intrusion was carried out on. $1.6 \mathrm{~mm}$-diameter, $7 \mathrm{~mm}$ -

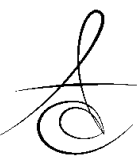


length ORLUS mini-implants (Ortholution, Seoul, South Korea) were inserted between the roots of $2^{\text {nd }}$ premolars and $1^{\text {st }}$ molars at the buccal mucogingival border and between the roots of the $1^{\text {st }}$ and $2^{\text {nd }}$ molars at the palatal side. An auxiliary 0.024-in SS wire was bonded to the palatinal surfaces of premolars and molars. Then $100 \mathrm{~g}$ of force was applied via elastic power chains (3M Unitek/ESPE, St Paul, Minn) from each mini-implant to the buccal and palatinal wires (Figure 1).

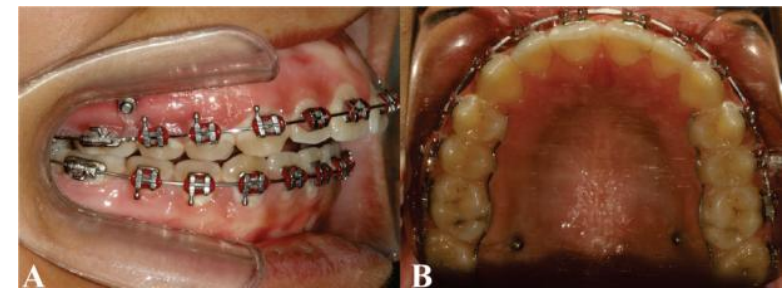

Figure 1: Lateral (A) and occlusal (B) views of the mechanic used in the intrusion of the posterior teeth.

Seven angular, 5 linear measurements were carried using Dolphin Imaging Software, Version 11.0 (Dolphin Imaging and Management Solutions, Los Angeles, California, USA) at pretreatment (T1), posttreatment (T2) and follow-up (T3) cephalograms (Figure 2).

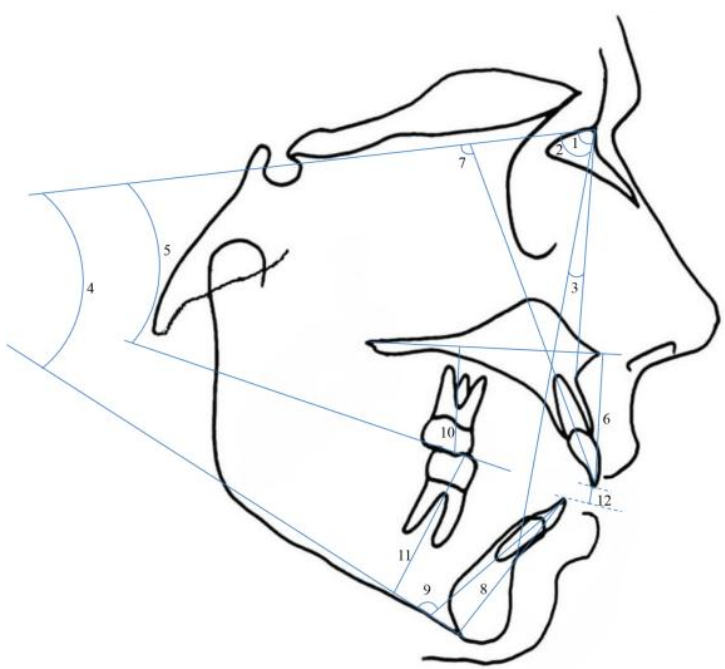

Figure 2: Skeletal and dental measurements: (1) SNA angle; (2) SNB angle; (3) ANB angle; (4) SN-GoGn angle; (5) SN-OP angle; (6) U1-PP distance; (7) U1-SN angle; (8) L1-MP distance; (9) L1-MP angle; (10) U6-PP distance; (11) L6-MP distance; (12) overbite, measured as the distance between incisal edges of maxillary and mandibular central incisors, perpendicular to functional occlusal plane Statistical Analysis
The sample size for each group based upon previous measures of open bite relaps ${ }^{15}$ indicated a minimum of 12.61 subjects for each group to detect a $1 \mathrm{~mm}$ group difference with $\mathrm{SD}=0.9 \mathrm{~mm}, \mathrm{a}=0.05,1$ $\beta=0.80$.

SPSS for Windows program (version 20.0, SPSS, Chicago, III) was used in the statistical analysis of data. Statistical significance was set at $p<0.05$. The normality of data was analyzed by the KolmogorovSmirnov test and statistical analysis was performed using parametric techniques. Descriptive statistics were reported for each parameter as mean and standard deviation. Paired t-test was used to determine the significance of mean changes in both groups during treatment and posttreatment periods while comparisons of mean changes between the groups were performed using independent samples t-test. For assessment of the method error, 20 randomly selected cephalograms were retraced and remeasured at a 2week interval, and intraclass correlation coefficients were calculated.

\section{RESULTS}

High intraclass correlation coefficients were obtained for the angular and linear measurements (> 0.86 and $>0.91$, respectively). Treatment time in EG was $2.1 \pm 0.4$ years while this duration was $1.8 \pm 0.3$ years in MG. The mean follow-up periods in EG and MG were 3.32 \pm 1.25 (range, 2.10-6.20) and 2.74 \pm 0.77 years (range, 2.05-4.34), respectively. There was no significant intergroup difference for this measurement; thus both groups were comparable in terms of followup periods. Also there was no significant intergroup difference concerning initial open bite amounts.

The cephalometric measurements for the EG and MG at T1, T2 and T3 are shown in Table 1. The changes in cephalometric parameters from pretreatment to posttreatment, and the significance thereof, in each group are described in Table 2, while comparisons between posttreatment and follow-up of each group together with intergroup differences are presented in Table 3.

At the end of the treatment, a significant increase of SNB and a decrease of SN-GoGn was observed in MG with a significant intergroup difference $(p<0.05)$. Also ANB showed a significant decrease in MG $(p<0.05)$ however no difference was found among the groups $(p>0.05)$. Maxillary and mandibular 
Table 1: Pretreatment (T1), Posttreatment (T2) and Follow-up (T3) cephalometric measurements of the groups (SD: standard deviation)

\begin{tabular}{|c|c|c|c|c|c|c|}
\hline & \multicolumn{3}{|c|}{ Extraction Group } & \multicolumn{3}{c|}{ Mini-Implant Group } \\
\hline & $\begin{array}{c}\text { T1 } \\
(\text { Mean } \pm \text { SD })\end{array}$ & $\begin{array}{c}\text { T2 } \\
(\text { Mean } \pm \text { SD })\end{array}$ & $\begin{array}{c}\text { T3 } \\
(\text { Mean } \pm \text { SD })\end{array}$ & T1 (Mean \pm SD) & T2 (Mean \pm SD) & T3 (Mean \pm SD) \\
\hline SNA & $81.02 \pm 3.03$ & $80.81 \pm 3.01$ & $81.13 \pm 2.84$ & $80.26 \pm 2.81$ & $80.43 \pm 2.66$ & $80.69 \pm 2.58$ \\
\hline SNB & $76.89 \pm 4.21$ & $77.15 \pm 4.13$ & $77.45 \pm 4.04$ & $75.81 \pm 3.10$ & $76.99 \pm 3.04$ & $76.74 \pm 3.06$ \\
\hline ANB & $4.13 \pm 2.67$ & $3.66 \pm 2.38$ & $3.68 \pm 2.57$ & $4.45 \pm 2.73$ & $3.44 \pm 2.84$ & $3.95 \pm 2.46$ \\
\hline SN-GoGn & $39.83 \pm 3.85$ & $39.91 \pm 3.62$ & $40.33 \pm 3.91$ & $40.55 \pm 4.12$ & $38.75 \pm 4.16$ & $39.43 \pm 4.26$ \\
\hline SN-OP & $22.03 \pm 4.72$ & $22.72 \pm 4.39$ & $22.30 \pm 4.03$ & $20.23 \pm 5.05$ & $19.39 \pm 4.68$ & $19.72 \pm 4.72$ \\
\hline U1-PP (mm) & $29.17 \pm 3.48$ & $32.05 \pm 3.07$ & $31.34 \pm 3.22$ & $31.64 \pm 3.04$ & $32.67 \pm 2.95$ & $32.91 \pm 3.15$ \\
\hline U1-SN & $110.05 \pm 8.58$ & $106.56 \pm 7.16$ & $107.79 \pm 7.39$ & $108.84 \pm 6.98$ & $107.77 \pm 7.50$ & $107.26 \pm 7.86$ \\
\hline L1-MP (mm) & $45.89 \pm 4.01$ & $47.72 \pm 3.34$ & $48.36 \pm 3.95$ & $45.78 \pm 4.20$ & $46.66 \pm 3.61$ & $47.08 \pm 3.97$ \\
\hline L1-MP & $97.51 \pm 6.42$ & $93.49 \pm 5.21$ & $94.57 \pm 4.84$ & $95.39 \pm 5.56$ & $96.42 \pm 4.79$ & $97.62 \pm 5.31$ \\
\hline U6-PP (mm) & $27.84 \pm 3.74$ & $28.93 \pm 4.04$ & $29.16 \pm 3.96$ & $27.11 \pm 3.97$ & $24.97 \pm 3.42$ & $25.58 \pm 3.58$ \\
\hline L6-MP (mm) & $35.21 \pm 2.73$ & $35 \pm 88 \pm 2.48$ & $36.64 \pm 2.41$ & $36.84 \pm 2.50$ & $37.37 \pm 2.13$ & $38.06 \pm 2.00$ \\
\hline Overbite (mm) & $-2.98 \pm 1.51$ & $1.41 \pm 0.98$ & $1.00 \pm 1.12$ & $-3.29 \pm 1.69$ & $1.93 \pm 1.22$ & $1.24 \pm 0.96$ \\
\hline
\end{tabular}

Table 2: Changes in each group and intergroup differences of the cephalometric measurements between pretreatment and posttreatment stages (SD: standard deviation, $* \mathrm{P}<0.05$ )

\begin{tabular}{|c|c|c|c|c|c|c|c|}
\hline & \multicolumn{3}{|c|}{ Extraction Group } & \multicolumn{3}{|c|}{ Mini-Implant Group } & Intergroup Difference \\
\hline & Mean & SD & $P$ & Mean & SD & $\mathrm{P}$ & $\mathrm{P}$ \\
\hline SNA & -0.21 & 1.01 & 0.451 & 0.17 & 0.87 & 0.478 & 0.296 \\
\hline SNB & 0.26 & 0.70 & 0.188 & 1.18 & 0.76 & $<0.001$ & $0.003^{*}$ \\
\hline ANB & -0.47 & 1.16 & 0.153 & -1.01 & 0.95 & $0.002^{*}$ & 0.189 \\
\hline SNGoGn & -0.34 & 0.78 & 0.127 & -1.80 & 1.03 & $<0.001$ & $<0.001$ \\
\hline SNOP & 0.69 & 1.98 & 0.215 & -0.84 & 1.40 & $0.043^{*}$ & $0.026^{*}$ \\
\hline U1-PP (mm) & 2.88 & 2.36 & $0.001^{*}$ & 1.03 & 1.02 & $0.002^{*}$ & $0.012^{*}$ \\
\hline U1-SN & -3.49 & 3.21 & $0.001^{*}$ & -1.07 & 3.01 & 0.206 & $0.047 *$ \\
\hline L1-MP (mm) & 1.83 & 1.30 & $<0.001$ & 0.88 & 1.09 & $0.010 *$ & $0.046^{*}$ \\
\hline L1-MP & -4.02 & 3.57 & $0.001^{*}$ & 1.03 & 2.96 & 0.233 & $<0.001$ \\
\hline U6-PP (mm) & 1.09 & 1.91 & 0.052 & -2.14 & 0.94 & $<0.001$ & $<0.001$ \\
\hline L6-MP (mm) & 0.67 & 1.19 & 0.055 & 0.53 & 1.36 & 0.169 & 0.774 \\
\hline Overbite (mm) & 4.39 & 1.32 & $<0.001$ & 5.32 & 1.14 & $<0.001$ & 0.077 \\
\hline
\end{tabular}

Table 3: Changes in each group and intergroup differences of the cephalometric measurements between posttreatment and follow-up stages (SD: standard deviation, * $\mathrm{P}<0.05$ )

\begin{tabular}{|c|c|c|c|c|c|c|c|}
\hline & \multicolumn{3}{|c|}{ Extraction Group } & \multicolumn{3}{c|}{ Mini-Implant Group } & Intergroup Difference \\
\hline & Mean & SD & P & Mean & SD & P & P \\
\hline SNA & 0.32 & 0.69 & 0.106 & 0.26 & 0.86 & 0.278 & 0.663 \\
\hline SNB & 0.30 & 0.62 & 0.093 & -0.25 & 0.81 & 0.269 & 0.054 \\
\hline ANB & 0.02 & 0.68 & 0.914 & 0.51 & 0.94 & 0.063 & 0.126 \\
\hline SNGoGn & 0.42 & 1.16 & 0.199 & 0.68 & 1.41 & 0.094 & 0.599 \\
\hline SNOP & -0.42 & 1.03 & 0.105 & 0.33 & 0.95 & 0.216 & 0.056 \\
\hline U1-PP (mm) & -0.71 & 1.02 & $0.022^{*}$ & 0.24 & 0.76 & 0.259 & $0.010^{*}$ \\
\hline U1-SN & 1.23 & 2.60 & 0.100 & -0.51 & 1.94 & 0.343 & 0.055 \\
\hline L1-MP (mm) & 0.64 & 1.18 & 0.063 & 0.42 & 1.03 & 0.151 & 0.604 \\
\hline L1-MP & 1.08 & 1.96 & 0.060 & 1.20 & 2.11 & 0.053 & 0.877 \\
\hline U6-PP (mm) & 0.23 & 0.42 & 0.061 & 0.61 & 0.52 & $0.001^{*}$ & 0.043 \\
\hline L6-MP (mm) & 0.76 & 1.47 & 0.077 & 0.69 & 1.25 & 0.059 & 0.893 \\
\hline
\end{tabular}

incisors extruded significantly in both groups with greater values measured in $E G(p<0.05)$. Uprighting of the incisors were significant only in EG while these inclination decreases were also significant compared with the MG $(p<0.05)$. The distance from mesiobuccal cusp tip of the $1^{\text {st }}$ upper molar to palatal plane significantly decreased in MG with significant intergroup difference $(p<0.05)$. The increase in overbite was significant for both groups $(p<0.05)$ with no intergroup difference $(p>0.05)$. 
At the follow-up, while a significant intrusion of upper incisors was observed in EG, significant molar extrusion of upper molars was seen in MG $(p<0.05)$. However, both manners of relaps had similar setbacks on overbite $(p>0.05)$. The clinically significant relaps rates were $7.14 \%$ (1 patient) and $9 \%$ (2 patients) in MG and EG, respectively.

\section{DISCUSSION}

This study offers sound comparability of the extraction treatment and posterior maxillary dental intrusion with no additional auxiliaries being used to control the vertical dimensions and closing the bite. The results of the current study demonstrated that moderate open bite cases can be treated equally successfully with extraction of $1^{\text {st }}$ premolars and intrusion of maxillary posterior teeth. The recidive rates of the forementioned two treatment methods were similar in the long term with an exception of different origins of relapse.

SNB and ANB showed significant changes in MG which was probably due to the counterclockwise rotation of the mandible caused by the intrusion of the maxillary molars. Our results agree with Xun et al. ${ }^{16}$, while Deguchi et al. ${ }^{15}$ detected greater quantitative difference compared with the present study but were not able to reach a significance level, probably due to the large interindividual differences. Mandibular plane angle showed a significant reduction only in MG as an outcome of maxillary molar and premolar intrusion in accordance with other studies ${ }^{4,14,15}$ implementing temporary anchorage devices. On the other hand, even though most of the extraction space had been reported to be used in forward movement of posterior teeth in EG, an expected finding of closing rotation of palatomandibular wedge was not observed. This was probably due to the protraction mechanics falling short of providing enough anchorage against general extrusive nature of orthodontic treatment ${ }^{17}$.

The primary preeminence of the current study over the previous reports investigating long-term stability of open-bite was the stringent inclusion criteria that did not permit interaction of several treatments methods in correcting the open bite. Namely, the earlier stability studies reported undifferentiated outcomes of cohorts either treated with fixed appliances supported with extraoral appliances $2,3,9,12$, or had extraction and non-extraction modalities pooled together ${ }^{3,4}$, or combined various extraction patterns ${ }^{9,12}$, or utilized different methods of intrusion $^{4,14}$, or incorporated maxillary expansion to the treatment of some of patients which is known to cause bite-opening itself $f^{9,11}$. Of the only study ${ }^{15}$ that compared the long-term effects of the conventional edgewise treatment with mini-implant anchored posterior intrusion, both groups had premolar extractions, thus it was not possible to differentiate the effects of extractions and posterior intrusion separately.

As for the treatment related changes, our results in EG agreed with previous studies $6,11,12,15,18$ reporting bite closure in the form of extrusion and uprighting of upper and lower incisors. On the other hand, in MG these changes were at a minimum with majority of the bite closure achieved by means of posterior intrusion. Upper and lower incisors extruded in both groups as a result of leveling at the initial stage of the treatment before commencing space closure or intrusion of the posterior teeth. The mean amount of extrusion was greater in EG most probably due to the uprighting of the incisors during space closure which relatively affected the vertical position of the incisor edges. In studies $3,6,11,12,18$ where posterior intrusion is not implemented, extrusion of the incisors is a common finding whether extractions are carried or not. Even in studies ${ }^{4,15}$ of posterior maxillary intrusion, incisors are shown to extrude similar to the current study. Hence, for the sake of stability, in cases of open bite with Y-form occlusal plane, instead of using a continuous archwire, sectional leveling of the anterior and posterior teeth has been proposed ${ }^{19}$. Significant retrusion of upper and lower incisors were observed in EG only, which was most probably induced by the mechanics used to close the extraction spaces. With respect to the intrusion mechanics applied, significant apical movement of posterior maxillary teeth was observed with significant intergroup differences which in turn resulted in a decrease of the occlusal plane angle in MG. This was in agreement with other studies ${ }^{20,21,22}$ using molar intrusion as a means of closing the bite. However, at the end of treatment both treatment mechanics were similarly effective in open bite treatment.

When origins of the relaps were investigated, significant posttreatment changes observed in EG

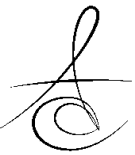


resulted from recidive of the upper incisor positions which were manifested as decreases in their distance to palatal plane, whereas in MG posttreatment increases in molar distances to palatal plane were detected. These two parameters also showed significant intergroup differences. Hence it is apparent that the mechanotherapy used to close the bite relapses significantly, but the expected observation of greater recidive of extrusion mechanics was not detected and both manners of relaps took its toll similarly on overbite decreases. Interestingly, even though mandibular incisors had also shown significant extrusions during the treatment with a significant intergroup difference, the extend of relapse was not significant as opposed observed amounts in upper incisors. This could be explained by Kuitert et al.'s3 findings of mandibular teeth acting in accordance with compensatory mechanism of the facial skeleton, and continuing their eruption during the retention phase as well.

Among two of the studies that investigated the differential effects of extraction on open bite relaps, de Freitas et al..$^{12}$ found similar outcomes with the current study. They observed no skeletal changes during the retention period while detecting significant eruption of upper and lower molars as contributory factors to the relaps of open bite. Though the molars in the current study had also shown eruption, these values did not reach a significance level which could be due to the relatively short observation period compared to a mean of 8.35 years in that study. Deguchi et al. ${ }^{15}$ comparing conventional treatments versus miniimplant intrusions, did not come up with any significant intragroup changes in any of the dental and skeletal parameters even though similar relaps patterns of molar elongation and incisor depressions were apparent in their data. Furthermore, they reported non-significant changes in overbite in an observation period of 2 years. However, they did not utilize only one treatment method in their groups, i.e., in extraction group anterior elastics either with accentuated-curve archwires or multiloop technique was used while in mini-implant group extractions were implemented in all the patients in combination with intrusion of the posterior teeth. It is plausible that the effects of treatments were enhanced by the consolidated mechanics. Their comparisons yielded a significant intergroup difference pertaining to the vertical position of the upper central incisors, similar to the present study, but no difference in upper molar positions were observed. With reference to the clinically significant relaps observed, Janson et al. ${ }^{11}$ reported this incidence as $38.1 \%$ in their nonextraction cases, while Freitas et $a / .^{12}$ stated this value to be $25.8 \%$ in their extraction patients. We observed this ratio to be $14.28 \%$ and $7.14 \%$ in our extraction and intrusion subjects, respectively. The reduced relaps rates in the current study could be attributed to the mean observation times being relatively short compared to the previous studies.

Limitations: Even though Baek et al. ${ }^{4}$ reported that most of the recidive that was due to rebounding of the molar positions occurred during the first year of retention, it has been shown that open bite relaps continue to take place up to 5 years in growing patients ${ }^{2}$. Hence the follow-up period of the present study which was around 3 years was slightly short.

\section{CONCLUSION}

- Patients who were subjected to premolar extractions showed overbite improvement without significant mandibular autorotation, whereas patients treated by the intrusion of posterior teeth demonstrated closing rotation of the mandible during open bite correction

- Relapse of the open bite treatment occurred by intrusion of the incisors in extraction group while elongation of the posterior teeth was the major factor in posttreatment recidive in mini-implant supported intrusion therapy.

- In terms of overbite reduction, both groups showed similarly significant relaps tendencies at the follow-up period

\section{REFERENCES}

1. Zuroff JP, Chen SH, Shapiro PA, Little RM, Joondeph DR, Huang GJ. Orthodontic treatment of anterior open-bite malocclusion: stability 10 years postretention. Am J Orthod Dentofacial Orthop 2010;137:302 e301-8.

2. Lopez-Gavito G, Wallen TR, Little RM, Joondeph DR. Anterior open-bite malocclusion: a longitudinal 10year postretention evaluation of orthodontically treated patients. Am J Orthod 1985;87:175-86.

3. Katsaros C, Berg R. Anterior open bite malocclusion: a follow-up study of orthodontic 
treatment effects. Eur J Orthod 1993;15:273-80.

4. Baek MS, Choi YJ, Yu HS, Lee KJ, Kwak J, Park YC. Long-term stability of anterior open-bite treatment by intrusion of maxillary posterior teeth. Am J Orthod Dentofacial Orthop 2010;138:396 e391-9.

5. Greenlee GM, Huang GJ, Chen SS, Chen J, Koepsell T, Hujoel P. Stability of treatment for anterior open-bite malocclusion: a meta-analysis. Am J Orthod Dentofacial Orthop 2011;139:154-69.

6. Kim YH, Han UK, Lim DD, Serraon ML. Stability of anterior openbite correction with multiloop edgewise archwire therapy: A cephalometric follow-up study. Am J Orthod Dentofacial Orthop 2000;118:43-54.

7. Remmers D, Van't Hullenaar RW, Bronkhorst EM, Berge SJ, Katsaros C. Treatment results and longterm stability of anterior open bite malocclusion. Orthod Craniofac Res 2008;11:32-42.

8. Chang YI, Moon SC. Cephalometric evaluation of the anterior open bite treatment. Am J Orthod Dentofacial Orthop 1999;115:29-38.

9. Janson G, Valarelli FP, Beltrao RT, de Freitas MR, Henriques JF. Stability of anterior open-bite extraction and nonextraction treatment in the permanent dentition. Am J Orthod Dentofacial Orthop 2006;129:768-74.

10. Reitan K, Rygh P. Biomechanical principles and reactions. In: Graber TM, Vanarsdall RL, editors. Orthodontics-current principles and techniques. St Louis, M0: Mosby; 1994, p.168-69.

11. Janson G, Valarelli FP, Henriques JF, de Freitas MR, Cancado RH. Stability of anterior open bite nonextraction treatment in the permanent dentition. Am J Orthod Dentofacial Orthop 2003; $124: 265-76$.

12. de Freitas MR, Beltrao RT, Janson G, Henriques JF, Cancado RH. Long-term stability of anterior open bite extraction treatment in the permanent dentition. Am J Orthod Dentofacial Orthop 2004;125:78-87.

13. Kucera J, Marek I, Tycova H, Baccetti T. Molar height and dentoalveolar compensation in adult subjects with skeletal open bite. Angle Orthod 2011;81:564-9.

14. Scheffler NR, Proffit WR, Phillips C. Outcomes and stability in patients with anterior open bite and long anterior face height treated with temporary anchorage devices and a maxillary intrusion splint.
Am J Orthod Dentofac Orthop 2014;146:594-602.

15. Deguchi T, Kurosaka H, Oikawa H, Kuroda $S$, Takahashi I, Yamashiro $\mathrm{T}$ et al. Comparison of orthodontic treatment outcomes in adults with skeletal open bite between conventional edgewise treatment and implant-anchored orthodontics. Am J Orthod Dentofacial Orthop 2011;139:S60-8.

16. Xun $C$, Zeng $X$, Wang $X$. Microscrew anchorage in skeletal anterior open-bite treatment. Angle Orthod 2007;77:47-56.

17. Staggers JA. A comparison of results of second molar and first premolar extraction treatment. Am J Orthod Dentofacial Orthop 1990;98:430-6.

18. Kucukkeles N, Acar A, Demirkaya AA, Evrenol B, Enacar A. Cephalometric evaluation of open bite treatment with $\mathrm{NiTi}$ arch wires and anterior elastics. Am J Orthod Dentofacial Orthop 1999;116:555-62.

19. Choi YJ, Kim DJ, Nam J, Chung CJ, Kim KH. Cephalometric configuration of the occlusal plane in patients with anterior open bite. Am J Orthod Dentofacial Orthop 2016;149:391-400.

20. Hart TR, Cousley RR, Fishman LS, Tallents RH. Dentoskeletal changes following mini-implant molar intrusion in anterior open bite patients. Angle Orthod 2015;85:941-8.

21. Erverdi N, Keles A, Nanda R. The use of skeletal anchorage in open bite treatment: a cephalometric evaluation. Angle Orthod 2004;74:381-90.

22. Çatalbaş B, Tan E. Treatment of open-bite with double vertical holding: case report. J Dent Fac Atatürk Uni 2015;Supp10:64-70.

23. Kuitert $R$, Beckmann $S$, van Loenen M, Tuinzing $B$, Zentner A. Dentoalveolar compensation in subjects with vertical skeletal dysplasia. Am J Orthod Dentofacial Orthop 2006;129:649-57.

\section{Yazışma Adresi}

Dr. Işıl ARAS, Research Assistant, Department of Orthodontics, Faculty of Dentistry, Ege University, 35080 Bornova Izmir, Turkey Phone number: +90 5335222926 e-mail address: isilaras@gmail.com Fax number: +90 2323114529 